(159)

\title{
Community and Industry Attitude Towards Using Prosopis juliflora as a Dry Matter Energy Source: A Case Study in Hambantota
}

\author{
Udadini K.M.E. and Bandara W.A.R.T.W. ${ }^{*}$ \\ ${ }^{I}$ Department of Zoology and Environmental Management, University of Kelaniya, Sri Lanka \\ *rangika@kln.ac.lk
}

\begin{abstract}
At present, Sri Lanka's first RAMSAR wetland, Bundala National Park, and surrounding area has affected with the rapid growth of Prosopis juliflora and it has become a threat to the native plant species of Salvadora persica and Gymnema sylvestra.

Past studies have shown that $P$. juliflora grown in Sri Lanka has a high energy potential as it contains high calorific value, high wood density, low moisture content and low ash content comparative to the current fuel wood species exist in the country. This study was conducted with the primary objective of investigating surrounding community and industry attitude towards using of $P$.juliflora as a dry matter fuel wood for their businesses. Total of 55 industries and 50 households from Thissamaharama, Ambalantota and Hambantota divisional secretaries were randomly selected and surveyed using face to face interviews with a pre tested questionnaire.

Study findings revealed that $90 \%$ of study respondents in both groups use fuel wood as their main energy source and most common fuel wood species are Manilkara hexandra, Drypetes sepiaria, and Fluggea leucopyrus. $90 \%$ of respondents in the community are able to identify the species and $93 \%$ of them are aware of different uses of P. juliflora. Even though awareness level about the advantages of using this species as an energy source is comparatively low majority of respondents identified high heat capacity as a favorable energy property of $P$. juliflora. Results of the industrial survey revealed that difficulties in handling due to presence of a thorny stem, difficulties in harvesting due to hardness of the stem, difficulties in transportation and lack of consistent supply as factors which hinder the usage of Prosopis juliflora as a fuel wood species. Further, study findings suggest that Prosopis juliflora is more appropriate for the small scale local industries such as bakery, salt and sweet manufacturing and existing such SCI require between $750-1500 \mathrm{~kg}$ of fuel wood per week.
\end{abstract}

As community and industry in the region prefer $P$. juliflora as a dry matter fuel wood, strengthening the supply chain management is crucial to make use of the species.

Keywords: Prosopis juliflora, Fuel wood, Invasive species

Proceedings of the International Forestry and Environment Symposium 2016, Department of Forestry and Environmental Science, University of Sri Jayewardenepura, Sri Lanka. 